\title{
Couples at risk from exposure to Zika virus should consider delaying pregnancy, says CDC
}

\author{
Michael McCarthy
}

Seattle

Men and women who have had possible exposure to the Zika virus - either from recent travel to an area where the virus is actively circulating or through sexual contact—-should wait for at least eight weeks after their possible exposure before trying to get pregnant, the US Centers for Disease Control and Prevention (CDC) has said in updated guidance released on 25 March. ${ }^{1}$

Of those who had had Zika diagnosed or who had symptoms of the infection — such as fever, rash, joint pain, or conjunctivitis - the updated guidance recommended that women waited for at least eight weeks after their symptoms first appeared before trying to get pregnant and that men waited for at least six months before having unprotected sex.

The time period was longer for men because the virus had been found to persist in semen for as long as two months. In making its recommendations, the CDC took the longest known periods of sexual transmission and multiplied them by three.

In a telephone conference with reporters, Denise Jamieson, of CDC's Division of Reproductive Health, said that, although not proved, "mounting evidence" supported a link between Zika virus infection and microcephaly, other birth defects, and miscarriage.

"Healthcare providers should discuss the risks of Zika, emphasize ways to prevent Zika virus infection, and provide information about safe and effective contraceptive methods," Jamieson said. "As part of their pregnancy planning and counseling with their healthcare providers, some women and their partners residing in areas with active Zika virus transmission might decide to delay pregnancy."

As it had in earlier guidance documents, the CDC recommended that men who lived in or had travelled to an area with active Zika virus transmission who had a pregnant partner should use a condom every time they had sex, whether it was vaginal, anal, or oral, or not have sex for the duration of the pregnancy.
In a guidance document on the prevention of sexual transmission of the virus, the CDC recommended that couples with men who had confirmed Zika or symptoms should consider using condoms or not having sex for at least six months after their symptoms began. ${ }^{2}$ In cases where the man travelled to an area with Zika but did not develop symptoms, the couple should consider using condoms or not have sex for at least eight weeks. Couples with men who live in areas where there is active Zika virus transmission but who have not developed symptoms might consider using condoms or not having sex while Zika was still active, the CDC said.

Couples who did not want to get pregnant should use the most effective contraceptive methods that they could use consistently and correctly, and, in addition, use condoms to prevent the sexual transmission of Zika. Couples in areas where Zika is active who were trying to get pregnant should consult with their healthcare provider to discuss the risks of infection, the CDC said.

As of 25 March the United States had seen no cases of locally acquired vector-borne Zika virus infections but 273 travel associated infections had been reported, including six that were sexually transmitted by a partner who had recently returned from abroad. Nineteen of the cases reported in the US were in pregnant women. The US territory of Puerto Rico, however, had been hard hit by the virus with 282 locally acquired infections, including 34 in pregnant women.

Petersen EE, Polen KN, Meaney-Delman D, et al. Update: interim guidance for health care providers caring for women of reproductive age with possible Zika virus exposure—United States, 2016. MMWR Morb Mortal Wkly Rep 2016. www.cdc.gov/mmwr/ volumes $/ 65 / \mathrm{wr} / \mathrm{mm} 6512 \mathrm{e} 2 \mathrm{er} . \mathrm{htm}$.

2 Oster AM, Russell K, Stryker JE, et al. Update: interim guidance for prevention of sexual transmission of Zika virus-United States, 2016. MMWR Morb Mortal Wkly Rep 2016. www.cdc.gov/mmwr/volumes/65/wr/mm6512e3er.htm.

Published by the BMJ Publishing Group Limited. For permission to use (where not already granted under a licence) please go to http://group.bmj.com/group/rights-licensing/ permissions 